\title{
FUZZY-КОНТРОЛЕР ПІДТРИМАННЯ МІКРОКЛІМАТУ В ПРИМІЩЕННІ ЗА ЗНАЧЕННЯМИ ІНДЕКСУ ДИСКОМФОРТУ
}

\author{
П.В. Новіков ${ }^{1}$, О.В. Степанець ${ }^{2}$, Р.П. Саков ${ }^{3}$ \\ 1,2,3 Національний технічний університет України "Київський політехнічний інститут імені Ігоря Сікорського" \\ ORCID: ${ }^{10000-0003-4857-7389, ~}{ }^{20000-0003-1865-4742, ~}{ }^{3} 0000-0002-3990-8126$ \\ E-mail: ${ }^{1}$ p.novikov@kpi.ua
}

Copyright (C) 2017 by author and the journal "Automation technological and business - processes". This work is licensed under the Creative Commons Attribution International License (CC BY). http://creativecommons.org/licenses/by/4.0/

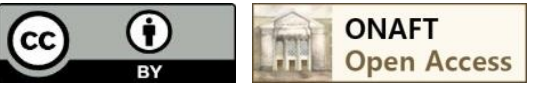

Анотація: Для систем керування мікрокліматом в приміщенні розглянуто алгоритм керування на основі підтримання бажаного індексу дискомфорту з використанням нечіткого логічного регулятора. Для оцінки впливу середовища на людину потрібно визначити не тільки кількісну величину окремих параметрів мікроклімату, а й результат їх загального впливу на людський організм. Досліджено існуючі методи комплексного керування мікрокліматом з позищї методів регулювання. Проаналізовано підхід щуодо визначення індексу дискомфорту. Значення індексу дискомфорту розбито на діапазони залежно від усереднених відчуттів комфортності умов в приміщенні для людини. Розглянуто засади теорії нечітких множин. Проведено синтез нечіткого логічного регулятора. Розроблено базу даних правил на основі розрахованих значень індексу дискомфорту. Спроектовано інтелектуальну систему автоматичного підтримання комфортних мікрокліматичних умов в приміщенні. На основі розрахованих значень індексу дискомфорту для усіх можливих варіантів значень температур сухого та зволоженого термометрів побудована база правил для ғизzу-контролера. Проведено компютерне моделювання отриманої системи керування мікрокліматом в приміщенні на основі функиій передачі температур сухого $і$ зволоженого термометрів. Результати математичного моделювання показали ефективність використання запропонованого алгоритму керування. Керуюча дія виробляється після обробки агрегованої інформації одразу від двох датчиків, там самим зменшуючи кількість непотрібних включень при малих коливаннях кожного окремо взятого параметра. 3 а результатами моделювання можна відзначити відповідність вимогам отриманої системи керування щзодо підтримання бажаного рівня індексу дискомфорту в приміщенні, мінімальну кількість включень виконавчого механізму, відсутність перерегулювання та економію електроенергіі.

Abstract: For microclimate control systems is proposed a control algorithm based on maintaining the desired discomfort index using a fuzzy logic controller. To assess the influence of the environment on humans, it is necessary to determine not only the quantitative value of individual microclimate parameters, but also the result of their overall impact on the human body. The existing complex methods of microclimate control are investigated. An approach to determine the index of discomfort has been analyzed. The values of the discomfort index are divided into ranges, depending on the average comfort sensations in the room for a person. The fundamentals of the theory of fuzzy sets are considered. The fuzzy logic controller is synthesized. A database of rules has been developed based on calculated values of the discomfort index. The intelligent system of automatic maintenance of comfortable microclimate conditions in the room is designed. Based on the calculated values of the discomfort index for all possible variants of the temperature values of dry and wet thermometers, a rule base for the fuzzy controller is built. The computer simulation of the obtained microclimate control system in the room is carried out based on the transfer functions of dry and wet thermometers. The results of mathematical modeling showed the effectiveness of using the proposed control algorithm. The control effect is made after processing the aggregated information directly from two sensors, thereby reducing the number of unnecessary inclusions for small fluctuations of each individual parameter. According to the results of modeling it can be noted compliance with the requirements of the received control system to maintain the desired level of discomfort index in the room, the minimum number of actuator inclusions, no overshoot and energy savings.

Ключові слова: нечітка логіка, нечіткий логічний регулятор, індекс дискомфорту, мікроклімат, кондиціювання, температура, вологість.

Keywords: fuzzy logic, fuzzy controller, discomfort index, microclimate, HVAC, temperature, humidity. 
Вступ

Розвиток технологій сприяє підвищенню рівня життя людей, у тому числі трансформує урбаністичне середовище в бік збільшення комфорту перебування в будівлях, разом 3 тим вирішуючи оптимізаційні задачі споживання енергоресурсів та енергозбереження.

Для керування сучасними системами кондиціювання повітря активно застосовуються принципово нові закони регулювання, що отримали назву «нейротехнологія і нечітка логіка» (Neuro\&Fuzzy logic) [1]. Критерієм функціонування та метою керування в них $\epsilon$ сукупність параметрів, що визначають комфорт навколишнього середовища для людини за величиною індексів дискомфорту $D_{n}[1]$.

Система оцінює параметри мікроклімату в приміщенні і автоматично обирає режим роботи. Вибір грунтується на практичному аналізі - за еталон беруться усереднені побажання людей, що нею користуються. Величини $D_{n}$ відображають рівні різноманітних факторів, від значення яких залежить комфорт людини: температура, вологість, інтенсивність повітряних потоків тощо.

Існуючі методи комплексного керування мікрокліматом 3 позиції методів регулювання

Останнім часом до традиційних методів керування параметрами мікроклімату в приміщенні, таких як двопозиційне керування або керування на основі ПІД алгоритму [1,2], додалися більш сучасні і складні алгоритми, такі як керування на основі нечіткої логіки $[1,2,3]$ та керування за допомогою багатовимірного лінійно-квадратичного цифрового регулятора у просторі стану [7,8].

Основна перевага нечітких логічних контролерів у порівнянні з традиційними підходами керування полягає в тому, що для проектування контролера не потрібна математична модель об’єкта керування [2]. Результати досліджень подібних систем викладено в роботах вчених Siham A. M. Almasani, Wadeea A. A. Qaid, Ahmed Khalid, Ibrahim A. A. Alqubati, Bova, S., Codara, P., Maccari, D., Marra, V. A. Нечіткі контролери розроблені на основі людських знань про поведінку системи. Крім того, контролери, які безпосередньо регулюють мікрокліматичні параметри, мають переваги над традиційними термостатичними системи. Основними перевагами є підвищення комфорту та економії енергії, що досягається завдяки урахуванню більшої кількості параметрів і факторів, які традиційними методами обробляти набагато складніше, на відміну від нечітких регуляторів або нейронних мереж [1]. Ще однією перевагою нечітких логічних регуляторів є стійкість до змін параметрів об'єкта керування, що пояснюється нелінійною природою подібних регуляторів [3].

Інший підхід запропоновано в роботах В.Г. Трегуба, I.М. Голінко, I. Є. Галицької [7,8]. В них запропонована методика розробки комплексної математичної моделі промислового кондиціонера у просторі стану. Методика дозволяє отримати комплексну модель промислового кондиціонера як єдиного багатовимірного об'єкта керування. На основі даної моделі запропонована методику синтезу лінійно-квадратичного цифрового регулятора, яка враховує логічні перемикання у роботі кліматичного обладнання для модифікованих алгоритмів керування за методами “точки роси”. На відміну від існуючих систем, які стабілізують температуру та відносну вологість повітря, запропонована методика регулювання температури та вологості повітря дозволяє зменшити, а в деяких режимах виключити взаємозв'язок між параметрами температури та вологості.

Постановка задачі

Основним завданням сучасної кліматологічної техніки є створення комфортних умов для життєдіяльності людини. Для оцінки впливу середовища на людину потрібно визначити не тільки кількісну величину окремих параметрів мікроклімату, а й результат їх загального впливу на людський організм. Деякі значення температури, вологості та швидкості вітру створюють умови, які є подразнюючими і навіть нестерпними для людини. Розрахувати вплив одного фактора на людину не складно, куди важче розрахувати вплив поєднання декількох факторів. Для формулювання якісного індексу комфорту були введені такі системи оцінки, як теплове навантаження середовища (WBGT) [5] та індекс дискомфорту (DI) [4]. Відповідно до індексу дискомфорту умови змінюються від комфортних до дещо подразнюючих, а потім до нестерпних.

Наведемо приклад урахування впливу вологості на стан людини.

Сприйняття теплоти або прохолоди є наслідком не тільки температури повітря, а і його вологості. Температура повітря $26{ }^{0} \mathrm{C}$ і вологість 50-60\% вважаються комфортними влітку, тоді як температура $22{ }^{0} \mathrm{C}$ буде комфортною взимку. Однак навіть температура $29{ }^{\circ} \mathrm{C}$ буде знаходитися в зоні комфорту, якщо вологість буде складати $50 \%$, тоді як та ж температура при вологості 70\% буде сприйматися високою і викликатиме відчуття «паркості». Для оцінки сумісного впливу температури і вологості на відчуття дискомфорту введений індекс [1]:

$$
D_{n}=0,72\left(\mathrm{t}_{\text {сух }}+\mathrm{t}_{\text {вол }}\right)+40,6 \text {, }
$$

де $\mathrm{t}_{\mathrm{cyx}}$ - температура сухого термометра;

$\mathrm{t}_{\text {вол }}$ - температура зволоженого термометра.

Такий підхід добре узгоджується з логічною системою обробки інформації «нечітка логіка» (fuzzy logic), яка застосовується в нечітких логічних регуляторах (НЛР). Нечітка логіка має переваги в порівнянні 3 використанням ПІД-регуляторів при обробці дуже складних процесів, нелінійних процесів, обробці експертних даних [1]. Таким чином актуальною є задача розробки системи керування мікрокліматом в приміщенні з НЛР на основі підтримання бажаного ступеня дискомфорту $D_{n}$. 
http://www.atbp.onaft.edu.ua/

\section{Таблиця 1. Ступені дискомфорту}

\begin{tabular}{|l|l|}
\hline \multicolumn{1}{|c|}{ Індекс дискомфорту $D_{n}$} & \multicolumn{1}{c|}{ Ступінь дискомфорту } \\
\hline 70 і менше & Комфортно \\
\hline $70-75$ & Деякі люди почувають себе некомфортно \\
\hline $75-80$ & $50 \%$ людей почувають себе некомфортно \\
\hline $80-85$ & Всі люди почувають себе некомфортно \\
\hline 85 і більше & Нестерпний дискомфорт \\
\hline
\end{tabular}

Основи теорії нечітких множин

Зважаючи на складність однозначного визначення оптимальної сукупності параметрів мікроклімату в реальному часі, що ускладнює процедуру постановки завдань автоматичним регуляторам, перспективним можна вважати підхід до керування із застосуванням нечіткої логіки. Застосування теорії нечітких множин дозволяє описувати нечіткі поняття і знання, оперувати цими знаннями і робити нечіткі висновки.

Нечітка множина являє собою сукупність елементів довільної природи, щодо яких не можна 3 повною впевненістю стверджувати, чи належить той чи інший елемент сукупності, що розглядається. Формально нечітка множина $A$ визначається як безліч впорядкованих пар або кортежів виду $<x, \mu_{A}(x)>$, де $x \in$ елементом деякого універсальної множини, або універсуму, $E$, а $\mu_{A}(x)$ - функція приналежності, яка ставить кожному 3 елементів х універсальної множини деяке дійсне число з інтервалу $[0,1]$. При цьому $\mu A(x)=1$ означає, що елемент $x$ з $E$ безумовно належить нечіткій множині $A$, а значення $\mu A(x)=0$ означає, що елемент $x$ з $E$ безумовно не належить нечіткій множині $A$.

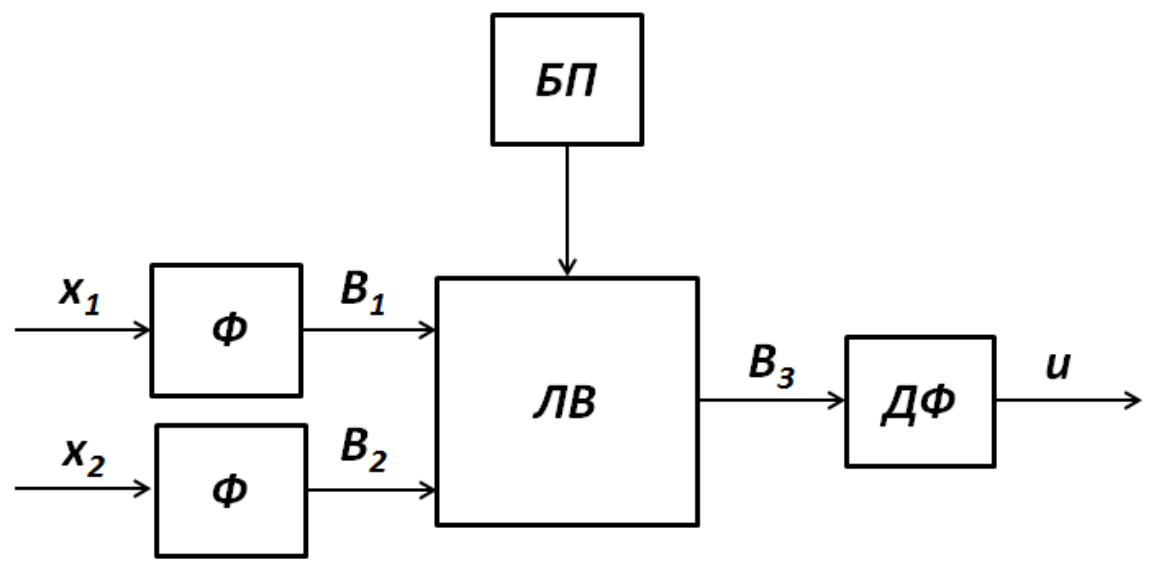

\section{Рис. 1 - Структура системи нечіткого виводу: $x_{1}, x_{2}-$ вхідні змінні; $B_{1}, B_{2}-$ вхідні нечіткі змінні; $B_{3}-$ вихідна нечітка змінна; $\boldsymbol{u}$ - вихідна змінна}

Розробка і застосування систем нечіткого виводу включають в себе послідовність етапів [6]:

1. формування бази правил БП систем нечіткого виводу, призначеної для формального подання емпіричних знань або знань експертів в проблемній області. У системах нечіткого виведення використовуються правила, в яких умови сформульовані в термінах нечітких лінгвістичних висловлювань.

2. фазифікація $\Phi$ вхідних змінних, що представляє собою процедуру знаходження значень функцій приналежності нечітких множин (термів) на основі звичайних (чітко визначених) вихідних даних. Метою етапу фазифікації $\epsilon$ встановлення відповідності між конкретним значенням окремої вхідної змінної системи нечіткого виведення і значенням функції приналежності відповідного їй значення вхідної лінгвістичної змінної.

3. операції блоку логічного висновку ЛВ, що виконує функції, аналогічні функціям обчислювального пристрою в класичній системі регулювання, і визначення ступеню істинності умов по кожному з правил, що зберігаються в БП.

4. дефазифікація ДФ вихідних змінних в системах нечіткого виведення, що представляє собою процедуру або процес знаходження звичайного (чітко визначеного) значення для кожної з вихідних лінгвістичних змінних. Мета дефаззіфікації полягає в тому, щоб, використовуючи результати логічного висновку, отримати значення кожної з вихідних змінних, яке може бути використане спеціальними пристроями, які не належать до системи нечіткого виведення. 


\section{Синтез НЛР для системи кондиціювання}

Розглянемо принцип керування кондиціонером для підтримання індексу дискомфорту $D_{n}$ в допустимих межах.

По-перше, потужність, 3 якою повинен працювати кондиціонер для охолодження повітря в приміщенні, визначається бажаною температурою, яку б ми хотіли мати в приміщенні. Температура в приміщенні $є$ першою лінгвістичною змінною НЛР і може приймати значення «мала», «середня», «велика». Приймемо діапазон змін сухого термометра від $18{ }^{\circ} \mathrm{C}$ до $29{ }^{\circ} \mathrm{C}$.

По-друге, як вже зазначалося раніше, комфортні кліматичні умови в приміщенні визначаються не лише температурою повітря, а і його вологістю. Тому другою лінгвістичною змінною НЛР може бути вологість, або температура зволоженого термометра, яка фігурую у формулі (1) і разом з показами сухого термометра однозначно визначає вологість в приміщенні. Діапазон змін зволоженого термометра будемо розглядати від $8{ }^{0} \mathrm{C}$ до $28{ }^{0} \mathrm{C}$. Можливий діапазон зміни температури зволоженого термометра є більшим, за діапазон змін сухого термометра, тому лінгвістичних змінних буде більше: «дуже низька», «низька», «задовільно низька», «задовільно висока», «висока», «дуже висока».

На основі формули (1) і діапазонів змін сухого і зволоженого термометрів сформуємо таблицю індексів дискомфорту для кожного значення температури.

В таблиці 2 наведені розраховані індекси дискомфорту $D_{n}$ у всьому діапазоні змін температур, а значення згруповані у блоки. Кожен із блоків можна віднести до певного ступеня дискомфорту згідно з таблицею 1.

Таблиця 2. Індекси дискомфорту

\begin{tabular}{|c|c|c|c|c|c|c|c|c|c|c|c|c|c|c|c|}
\hline & & & \multicolumn{13}{|c|}{ Температура зволоженого термометра } \\
\hline & & & \multicolumn{4}{|c|}{ Дуже мала } & \multicolumn{3}{|c|}{ Мала } & \multicolumn{3}{|c|}{ Задовільно мала } & \multicolumn{3}{|c|}{ Дуже велика } \\
\hline & & & 8 & 9 & 10 & 11 & 12 & 13 & 14 & 15 & 16 & & 26 & 27 & 28 \\
\hline \multirow{12}{*}{ 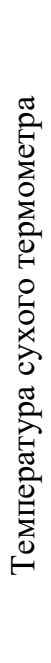 } & \multirow{4}{*}{ 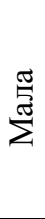 } & 18 & 59 & 60 & 61 & 61 & 62 & 63 & 64 & 64 & 65 & 6 & & & \\
\hline & & 19 & 60 & 61 & 61 & 62 & 63 & 64 & 64 & 65 & 66 & 6 & & & \\
\hline & & 20 & 61 & 61 & 62 & 63 & 64 & 64 & 65 & 66 & 67 & 6 & & & \\
\hline & & 21 & 61 & 62 & 63 & 64 & 64 & 65 & 66 & 67 & 67 & 6 & & & \\
\hline & \multirow{4}{*}{ 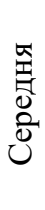 } & 22 & 62 & 63 & 64 & 64 & 65 & 66 & 67 & 67 & 68 & 6 & & & \\
\hline & & 23 & 63 & 64 & 64 & 65 & 66 & 67 & 67 & 68 & 69 & & & & \\
\hline & & 24 & 64 & 64 & 65 & 66 & 67 & 67 & 68 & 69 & 69 & & & & \\
\hline & & 25 & 64 & 65 & 66 & 67 & 67 & 68 & 69 & 69 & 70 & & & & \\
\hline & \multirow{4}{*}{ 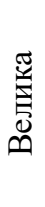 } & 26 & 65 & 66 & 67 & 67 & 68 & 69 & 69 & 70 & 71 & & 78 & & \\
\hline & & 27 & 66 & 67 & 67 & 68 & 69 & 69 & 70 & 71 & 72 & & 79 & 79 & \\
\hline & & 28 & 67 & 67 & 68 & 69 & 69 & 70 & 71 & 72 & 72 & & 79 & 80 & 81 \\
\hline & & 29 & 67 & 68 & 69 & 69 & 70 & 71 & 72 & 72 & 73 & & 80 & 81 & 82 \\
\hline
\end{tabular}

Наприклад блок з «середньою» температурою сухого термометра і «задовільно малою» температурою зволоженого термометра можна вважати таким, в якому забезпечені комфортні мікрокліматичні параметри, тоді як блок, що відповідає «великій» температурі сухого термометра і «великій» температурі зволоженого термометра за значеннями індексів дискомфорту відповідає некомфортним мікрокліматичним умовам. В той же час блок із «малою» температурою сухого термометра і «дуже малою» температурою зволоженого термометра хоч і відповідає згідно таблиці 1 комфортним мікрокліматичним умовам, але все ж характеризується занадто низькою вологістю, в межах 18 \%, що є дуже малим значення, тому даний блок також можна охарактеризувати як такий, що не відповідає комфортним умовам в приміщенні. На базі вище розглянутих міркувань можна побудувати базу правил для нечіткого регулятора.

В таблиці 3 наведена база правил НЛР підтримання мікроклімату в приміщенні.

Вихідною величиною НЛР є керуюча дія на компресор холодоагенту, якій присвоюються наступні терми: «велика від’ємна» (NB), «від’ємна» (N), «нульова» (ZE), «додатна» (Р), «велика додатна» (РВ). Тобто при комфортних умовах керуючої дії не відбувається, і компресор працює із заданою потужністю. При наявності відхилень від комфортних умов НЛР виробляє керуючу дію в сторону збільшення або зменшення потужності компресора доти, доки не буде компенсоване збурення. 
Автоматизація технологічних і бізнес-процесів Volume 10, Issue 4 /2017

http://www.atbp.onaft.edu.ua/

Таблиця 3. База правил НЛР

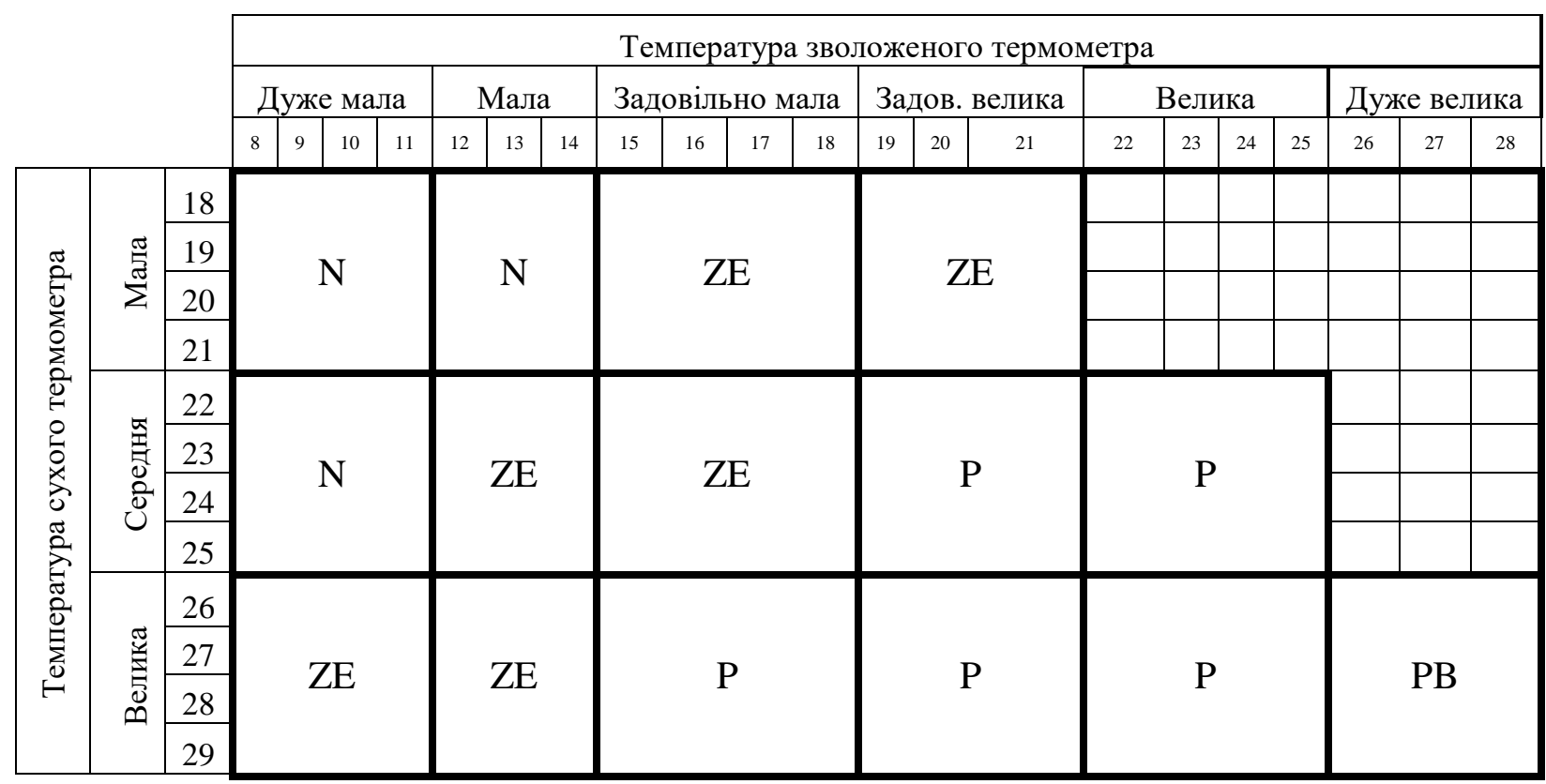

Структурна схема регулювання мікроклімату в приміщенні на базі НЛР наведена на рис. 2.

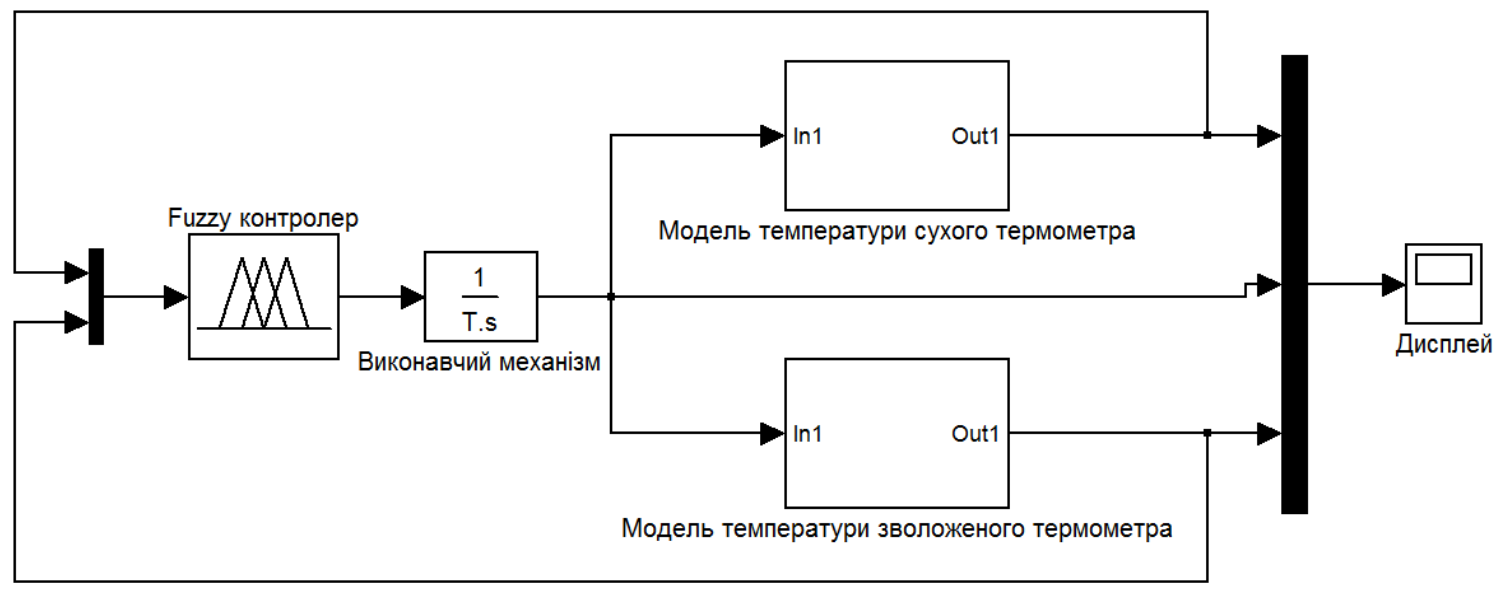

Рис. 2 - Структурна схема регулювання мікроклімату в приміщенні на базі НЛР

Найбільш простими і розповсюдженими на практиці функціями приналежності (ФП) лінгвістичних змінних $є$ трикутні ФП, математичний опис яких задається у вигляді [2]:

$$
\mu_{1}(u)=(1-u), \mu_{2}(u)=u, 0 \leq u \leq 1
$$

В даній статті як алгоритм нечіткого виводу використовується алгоритм Мамдані, або як його це називають, алгоритм «мінімаксного» виводу. Для розрахунку результуючої нечіткої множини вихідної змінної в цьому алгоритмі використовуються операції логічного мінімуму ( $\mathrm{min})$ на етапі нечіткого виводу і операції логічного максимуму (max) на етапі композиції.

В блоці дефазифікації отримана результуюча функція приналежності для керуючого впливу на об'єкт керування перетворюється в числову величину. В даній статті для отримання чіткого виводу використовувався метод визначення «центру тяжіння», в якому чітке числове значення визначається згідно формули:

$$
u_{c}=\frac{\int_{U_{1}}^{U_{2}} u \mu_{c}(u) d u}{\int_{U_{1}}^{U_{2}} \mu_{c}(u) d u}
$$


де $u_{c}$ - результат дефазифікації,

http://www.atbp.onaft.edu.ua/

$U_{1}, U_{2}$ - межі змін лінгвістичної змінної $u$,

$\mu_{\mathrm{c}}(u)$ - результуюча ФП.

Набір вхідних і вихідних лінгвістичних змінних і їх ФП наведений на рисунках 3-5.

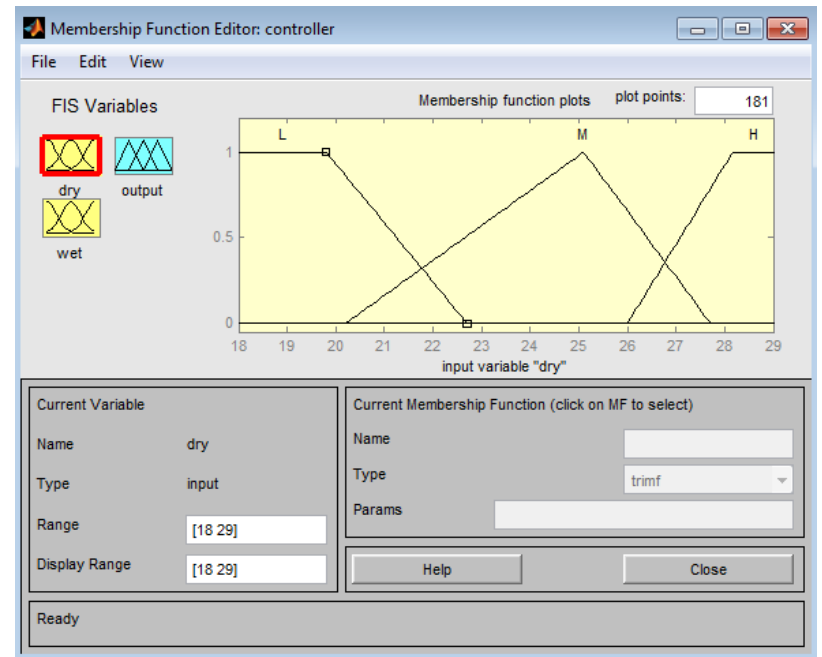

Рис. 3 - ФП температури сухого термометра

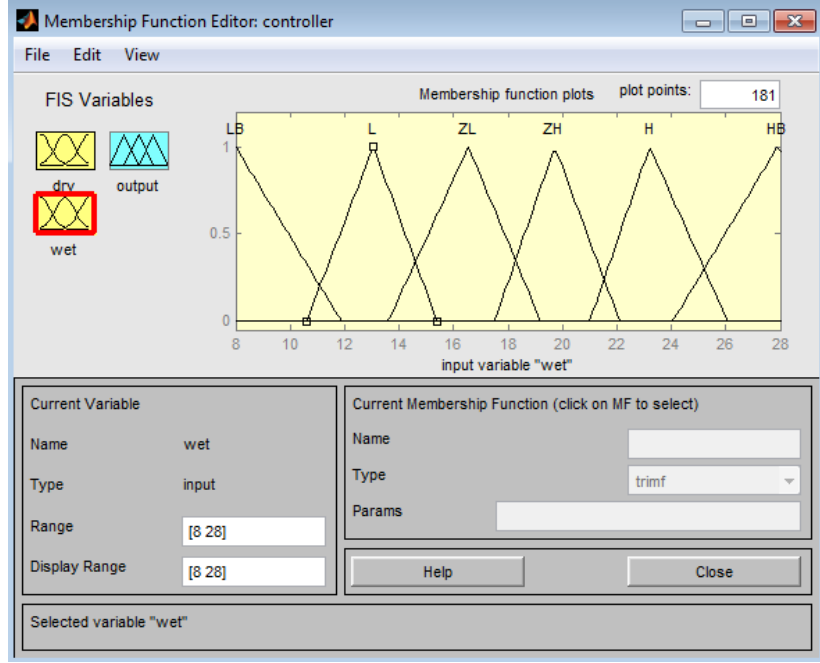

Рис. 4 - ФП температури зволоженого термометра

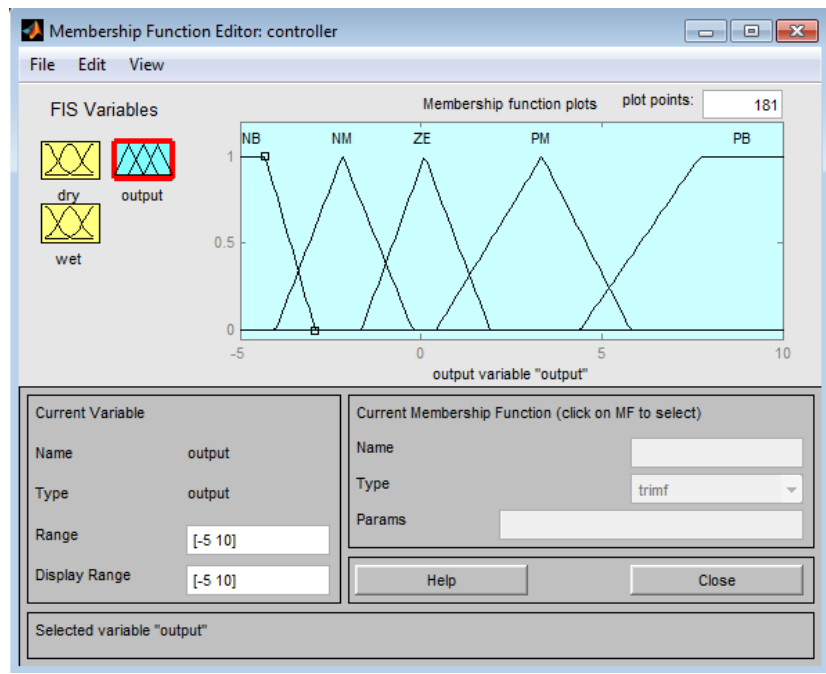

Рис. 5 - ФП вихідної величини НЛР 
Моделювання роботи системи керування мікрокліматом в приміщенні

Для оцінки якості роботи синтезованої системи регулювання важливе значення мають моделі об'єктів керування [3]. Обидві моделі температур, які є вхідними параметрами НЛР, описуються диференційними рівняннями 1-го порядку із запізненням (4) - (5).

Температура сухого термометра:

$$
186 \dot{t}_{c y x}(t)+t_{c y x}(t)=0.11 u(t-160)
$$

Температура зволоженого термометра:

$$
405 \dot{t}_{3 в о л}(t)+t_{\text {звол }}(t)=0.28 u(t-184)
$$

Функція передачі температури сухого термометра:

$$
W_{c y x}(s)=\frac{0.11}{186 s+1} e^{-160 s}
$$

Функція передачі температури зволоженого термометра:

$$
W_{\text {звол }}(s)=\frac{0.28}{405 s+1} e^{-184 s}
$$

Моделювання системи регулювання мікроклімату в приміщенні проводилося в середовищі Simulink MATLAB 3 використанням блоку Fuzzy Logic Controller with Rule Viewer для реалізації спроектованого НЛР.

На рисунку 6 наведені перехідні процеси в системі регулювання з НЛР.

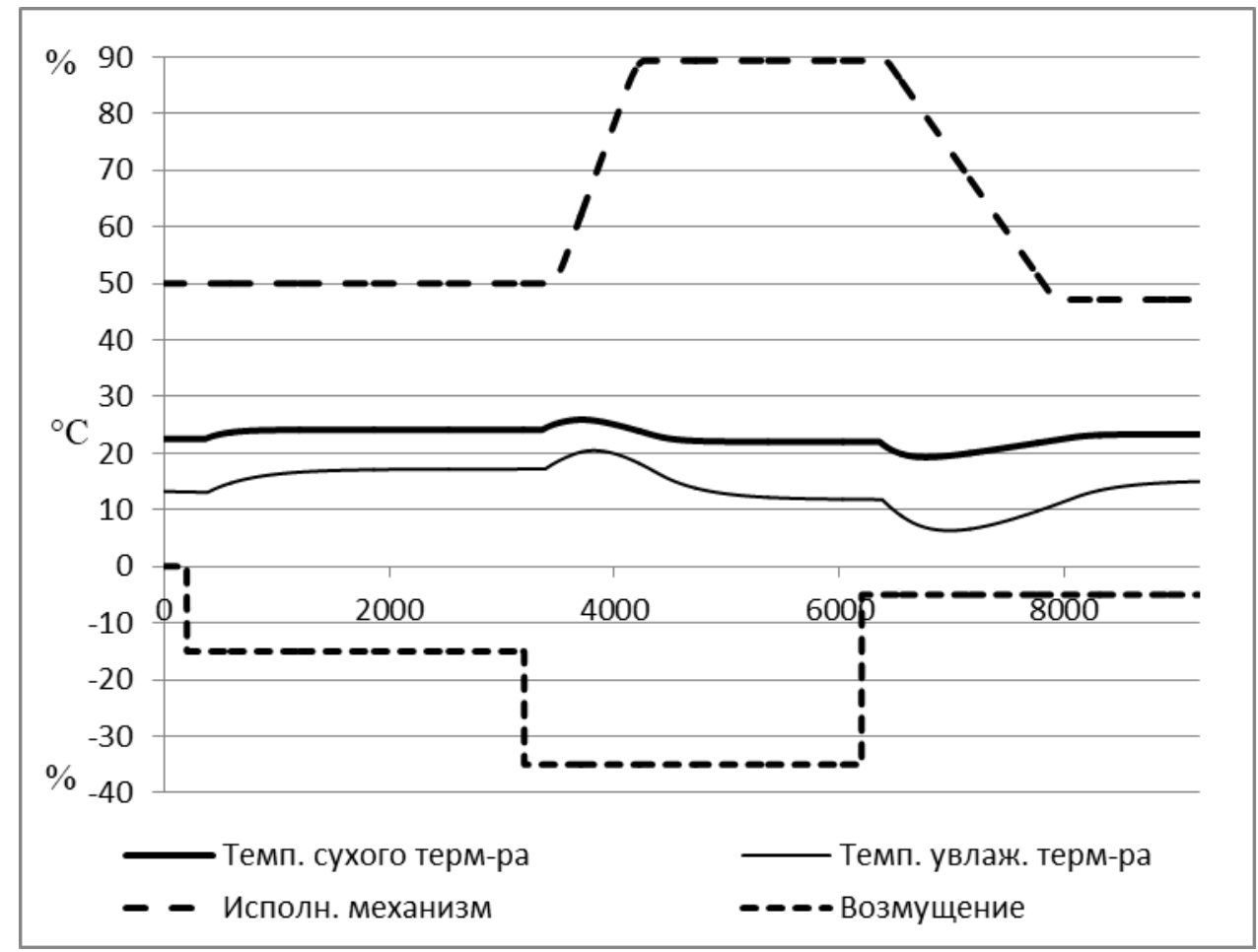

Рис. 6 - Перехідні процеси в системі регулювання з НЛР

Моделювання відбувалося протягом 9200 секунд. За цей час на систему почергово було здійснено три збурення в еквіваленті зміни положення регулювального органа на $-15 \%,-20 \%$ i $+30 \%$. Кожне збурення наносилося в усталеному режимі системи.

Спочатку наносилося збурення -15\%. Перехідний процес наведений на проміжку 0-3000 сек. Як видно 3 рис. 5 при цьому НЛР не виробляв ніякої керуючої дії, так як в сукупності параметри все одно забезпечували допустимий індекс дискомфорту.

Потім було нанесене додаткове збурення -20\%. Перехідний процес наведений на проміжку 3000-6000 сек. Додаткове збурення зумовило зміну температур сухого і зволоженого термометрів до недопустимих значень і НЛР почав виробляти керуючу дію для компенсації нанесеного збурення. Швидкість зміни положення РО обмежена постійною часу виконавчого механізму, яка в даній моделі становила 40 с. Після того, як значення температур повернулися в допустимі межі, сигнал керування перестав поступати на виконавчий механізм. 
Третє збурення наносилося в іншу сторону величиною $+30 \%$. Аналогічно до другого перехідного процесу, НЛР виробляв керуючу дію в протилежну сторону поки не було досягнуто мінімально допустимих значень температур сухого і зволоженого термометрів.

Варто зауважити, що у всіх перехідних процесах параметри не поверталися до тих значень, які були перед нанесенням збурення, як це спостерігається в класичних системах з ПІ- та ПІД-регуляторами. Але з іншого боку в даній системі і немає конкретної уставки температури сухого чи зволоженого термометра, а параметром, який регулюється, по суті $є$ індекс дискомфорту $D_{n}$, який $\epsilon$ непрямим показником і розраховується на основі обох температур.

Висновки

В системі з НЛР температура уставки постійно корегується виходячи з поточних значень температури сухого і зволоженого термометрів. Підтримання мінімально допустимого індексу дискомфорту в приміщенні забезпечує зниження енерговитрат та усуває непотрібні регулювальні дії при малих відхиленнях вимірюваних параметрів, якими $€$ температура і вологість в приміщенні.

Розглянута система регулювання мікроклімату в приміщенні на основі визначення індексу дискомфорту забезпечує більш грубе регулювання по відношенню до прямих вимірюваних параметрів, але тим не менш забезпечує комфортні мікрокліматичні умови в приміщенні завдяки закладеній в НЛР базі правил.

\section{Література}

[1] Бондарь Е.С. Автоматизация систем вентиляции и кондиционирования воздуха: [Учеб. пособие]/ Е.С. Бондарь, А.С. Гордиенко, В.А. Михайлов, Г.В. Нимич. Под общ. ред. Е.С. Бондаря - К.: ТОВ «Видавничий будинок «Аванпост-Прим» 2005. - 560 с.: ил. - Библиогр.: с. 548-549.

[2] Bova S., Logical analysis of Mamdani-type fuzzy inference, I theoretical bases [Текст] / S. Bova, P. Codara , D. Maccari, V. A. Marra // IEEE International Conference on Fuzzy Systems, Barcelona. - 2010. -P. 1-8.

[3] Siham A. M. Almasani, Fuzzy Expert Systems to Control the Heating, Ventilating and Air Conditioning (HVAC) Systems [Текст] / Siham A. M. Almasani, Wadeea A. A. Qaid, Ahmed Khalid, Ibrahim A. A. Alqubati // International Journal of Engineering Research Technology (IJERT). - 2015. - Vol. 4. - P.808-815.

[4] Thom, E.C., The discomfort index [Текст] / Е.C. Thom // Weather wise. - 1959. - Vol. 12. - P.57-60.

[5] Grahame M.Budd, Wet-bulb globe temperature (WBGT) - its history and its limitations [Текст] / M.Budd Grahame // Journal of Science and Medicine in Sport. - 2008. P. 20-32.

[6] Новиков С. И. Методы нечеткой логики в задачах автоматизации тепловых процессов электростанций [Текст] / С. И. Новиков, В. Р. Шахнович, А. В. Сафронов // Вестник ИГЭУ. - ГОУВПО «Ивановский государственный энергетический университет имени В.И. Ленина», 2010. - № 4. - С. 72-75. - ISSN 2072-2672.

[7] Голінко I. М. Оптимізація багатовимірних систем керування для комплексів штучного мікроклімату [Текст] / I. М. Голінко, І. Є. Галицька // Прикарпатський вісник НТШ. Число. - 2016. - № 1. - С. 61-73. - Режим доступу: http://nbuv.gov.ua/UJRN/Pvntsh_ch_2016_1_6

[8] Голінко I. М. Аналіз системи керування для штучного мікроклімату за методом "точки роси" [Текст] / I. М. Голінко, В. Г. Трегуб // Восточно-Европейский журнал передовых технологий. - 2011. - № 2. - С. 53-55.

\section{References}

[1] E.S. Bondar, A.S. Hordienko, V.A. Mihailov, G.V. Nimich, Ventilation and air conditioning systems automation. Kiev: LLC Tipografiya "Avanpost-Prim", 2005, pp. 95-101.

[2] S. Bova , P. Codara, D. Maccari , V. A. Marra, Logical analysis of Mamdani-type fuzzy inference, I theoretical bases, IEEE International Conference on Fuzzy Systems, Barcelona, pp. 1-8, 2010.

[3] A. M. Siham Almasani, A. A. Wadeea Qaid, Ahmed Khalid, A. A. Ibrahim Alqubati, Fuzzy Expert Systems to Control the Heating, Ventilating and Air Conditioning (HVAC) Systems, International Journal of Engineering Research \& Technology, pp. 808-815, 2015.

[4] E.C. Thom, The discomfort index, Weather wise, vol. 12, pp.57-60, 1959.

[5] M.Budd Grahame, Wet-bulb globe temperature (WBGT) - its history and its limitations, Journal of Science and Medicine in Sport, pp. 20-32, 2008.

[6] S. I. Novikov, V. R. Shahnovich, A. V. Safronov, Fuzzy Logic Methods in the Tasks of Thermal Processes Automation of Power Plant, Vestnik of Ivanovo State Power Engineering University, IGEU named after V.I.Lenin, vol. 4, pp. 72-75, 2010.

[7] I. M. Golinko, I. Y. Galitska, Optimization of multidimensional control systems for complexes of artificial microclimate, Prykarpatskiy visnyk NTS, Chislo, vol. 1, pp. 61-73, 2016.

[8] I. M. Golinko, V. G. Tregub, Analysis of control systems for artificial microclimate on an "dew point", EasternEuropean Journal of Eenterprise Technologies, vol. 2, pp. 53-55, 2011. 